\title{
Development of a Promising Area of Diversification in Helicopter Industry
}

\author{
Yuriy V. Krivolutsky \\ Moscow Aviation Institute (MAI), Department of Management and Marketing of High Technology Industries, \\ Volokolamskoe Highway, 4, 125993, Moscow, Russia
}

\begin{abstract}
Many countries have main pipeline systems that deliver hydrocarbon deposits from fields to their places of consumption and for export. Pipelines during operation require constant maintenance, industrial safety monitoring, repair, and protection. An accident there entails significant loss of product, additional financial costs, tangible environmental damage, and, in some cases, loss of life. To prevent it, it is necessary to use various types of monitoring, including aerospace. In addition to existing control methods, unmanned aerial vehicles (UAV) of a helicopter type with a long flight range can become a modern high-tech tool for solving problems of monitoring main pipelines. For a helicopter manufacturing enterprise, this is a new perspective area in diversifying its production and commercial activities.
\end{abstract}

Keywords - diversification, emergency situations, market segment, monitoring methods, pipeline transport, unmanned aerial vehicles

\section{Introduction}

In the world export of goods, the cost of energy resources occupies a significant share and in recent years, depending on the price level, fluctuates within $10-15 \%$. Currently, the countries with the largest energy potential are the following: United States of America (USA), China, and Russia.

DOI: 10.18421/TEM94-24

https://doi.org/10.18421/TEM94-24

Corresponding author: Yuriy V. Krivolutsky, Moscow Aviation Institute (MAl), Moscow, Russia.

Email: krivolutsky-yu@mail.ru

Received: 24 June 2020.

Revised: 30 October 2020.

Accepted: 05 November 2020.

Published: 27 November 2020.

(cc)BY-NC-ND (C) 2020 Yuriy V. Krivolutsky; published by UIKTEN. This work is licensed under the Creative Commons Attribution-NonCommercial-NoDerivs 4.0 License.

The article is published with Open Access at www.temjournal.com
The fuel industry created in these countries has $32 \%$ of world oil production and $43 \%$ of world gas production. These data are given in Table 1. [1].

Oil is in the first place from the six primary energy sources, it had $32.3 \%$ of global energy production in 2018, gas had 24\%, and coal had 28.3\% (China has $46.7 \%$ of global coal production).

Hydrocarbon production requires their transportation from fields to places of their use or processing to various economic regions or for export. Over the years, powerful developed pipeline systems for gas, oil, and oil product pipelines have developed in the fuel and energy complexes of the USA and Russia. To a lesser extent, this applies to China. Nevertheless, according to forecasts, the total length of the oil and gas pipeline system in China will reach $240000 \mathrm{~km}$ by 2025 , including $163000 \mathrm{~km}$ of main gas pipelines, $37000 \mathrm{~km}$ of main oil pipelines, 40 $000 \mathrm{~km}$ main oil products pipelines. The main indicators of the length of the main oil, gas and oil product pipelines in the USA, Russia and China are shown in Figure 1.

Pipeline systems during operation require constant maintenance, industrial safety monitoring, repair, or replacement of individual pipe sections.

An accident on the linear part of the pipeline as one of the elements of an energy-intensive technical system entails significant losses of the product, financial costs, significant environmental damage, and, in some cases, loss of life. In case of failure (accident) of the gas pipeline, $0.5-10$ million $\mathrm{m}^{3} /$ day of gas with significant destructive impact is lost, in case of failure of the oil pipeline, 100-1000 million $\mathrm{m}^{3} /$ day of oil with large pollution of the territory is lost. The average pollution area during an accident at an oil pipeline is $773 \mathrm{~m}^{2}$ [2]. The economic damage from accidents in Russia in 2018 amounted to 190 799000 rubles, 2139000 rubles of which were environmental damage. Only on the main pipelines of Russia in the period from 2014 to 2018, about 10 accidents occurred on average annually with an average intensity of 0.0386 accidents per $1000 \mathrm{~km}$ [3]. The dynamics of accidents at gas, oil and oil product pipelines is shown in Figure 2. 
Table 1. Production and consumption of fuel and energy resources by their types in 2018 (M toe)

\begin{tabular}{|c|c|c|c|c|}
\hline Country & Indicator & Oil & Gas & Total energy resources of all types \\
\hline \multirow{3}{*}{ USA } & Production & 669 & 715 & 2110 \\
\cline { 2 - 4 } & Consumption & 920 & 703 & 2301 \\
\cline { 2 - 4 } & Balance & -251 & 12 & -191 \\
\hline \multirow{3}{*}{ Russia } & Production & 563 & 576 & 1448.3 \\
\cline { 2 - 4 } & Consumption & 152 & 391 & 720.0 \\
\cline { 2 - 4 } & Balance & 411 & 185 & 728 \\
\hline \multirow{3}{*}{ China } & Production & 189 & 139 & 2640 \\
\cline { 2 - 4 } & Consumption & 641 & 243 & 3274 \\
\cline { 2 - 4 } & Balance & -452 & -104 & -634 \\
\hline \multirow{3}{*}{ Total in the world } & Production & 4474 & 3326 & 13838 \\
\cline { 2 - 4 } & Consumption & 4662 & 3309 & 13864 \\
\cline { 2 - 4 } & Balance & -188 & 17 & -25 \\
\hline
\end{tabular}

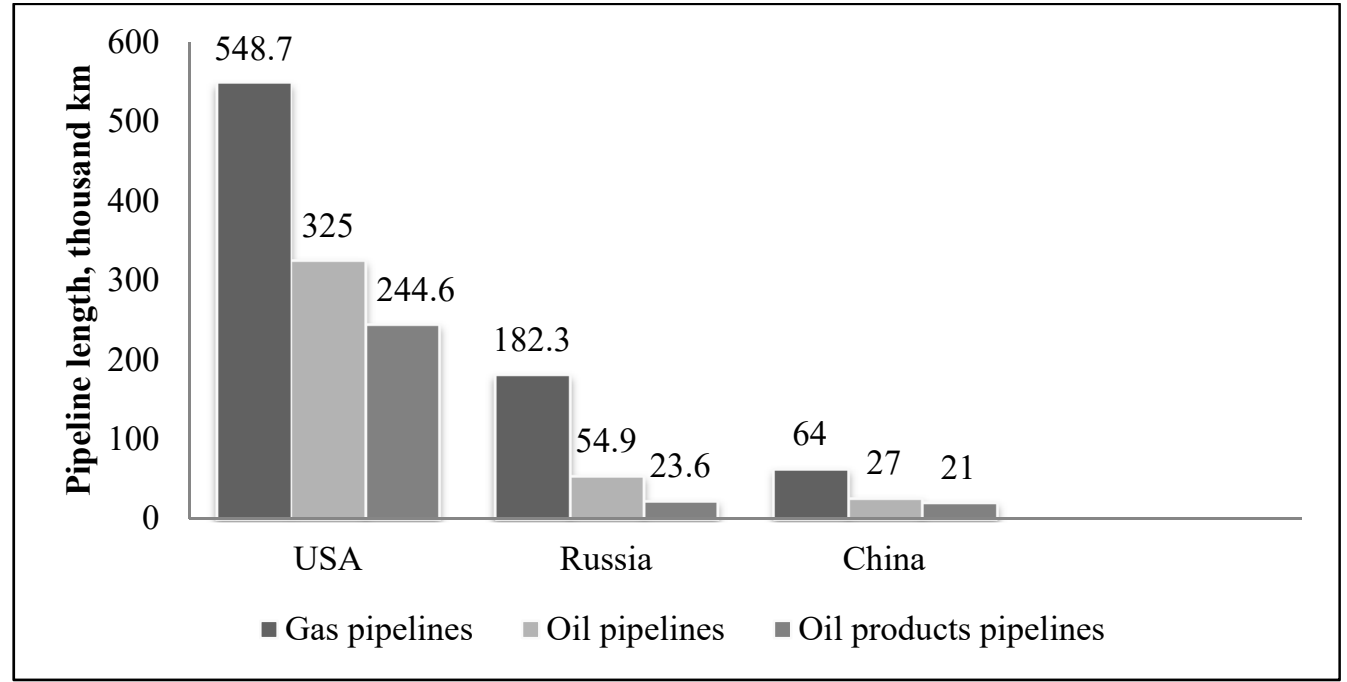

Figure 1. Length of main pipelines in the USA, Russia and China

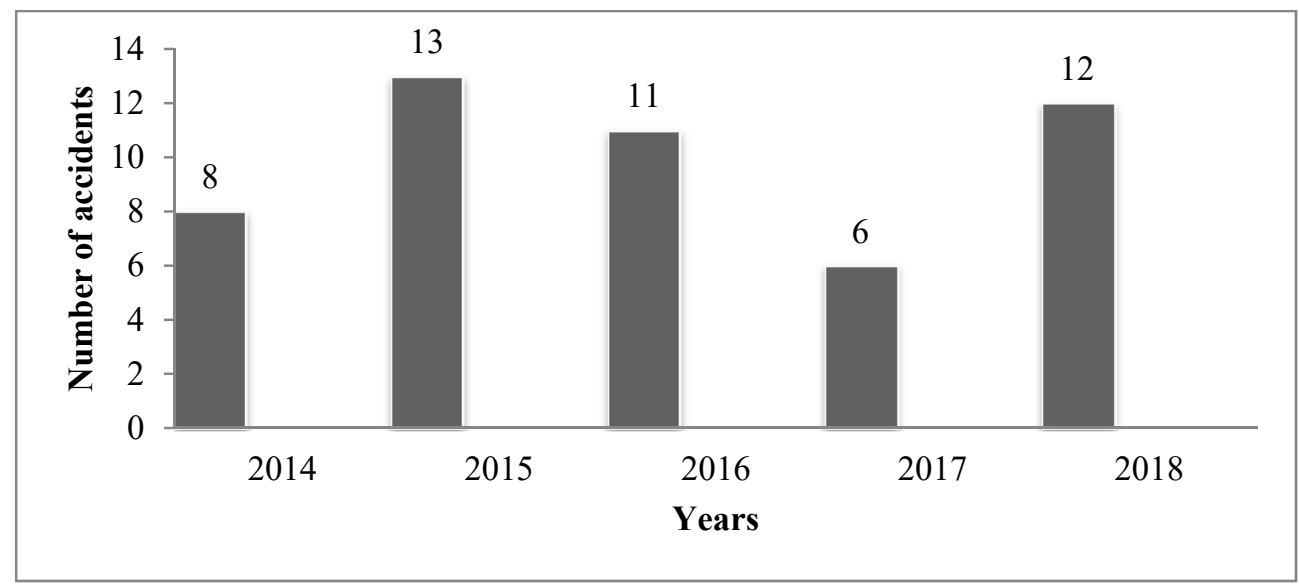

Figure 2. Accident dynamics at gas, oil and oil product pipelines

The main causes of accidents include the depressurization of the walls of the pipe and its parts and destruction of technical devices as a result of loss of strength. They can be caused by a pipe insulation failure, the presence of fistulas, cracks, leaks, and change in the spatial position of the pipeline from environmental influences. Pipe insulation failure often results from unauthorized taps that have turned into a highly profitable business. The amount of counterfeit fuel is estimated at more than 6 billion dollars annually. The costs of eliminating the tie-in, losses from equipment downtime, and stopping the supply during the emergency recovery work are about 50000 dollars. The pipeline system occupies more than $35 \%$ of the territory of Russia and most of the pipelines are not protected. In Figure 3. there is the number of unauthorized tie-ins into the main oil and oil product pipelines for the period 2014-2019. 


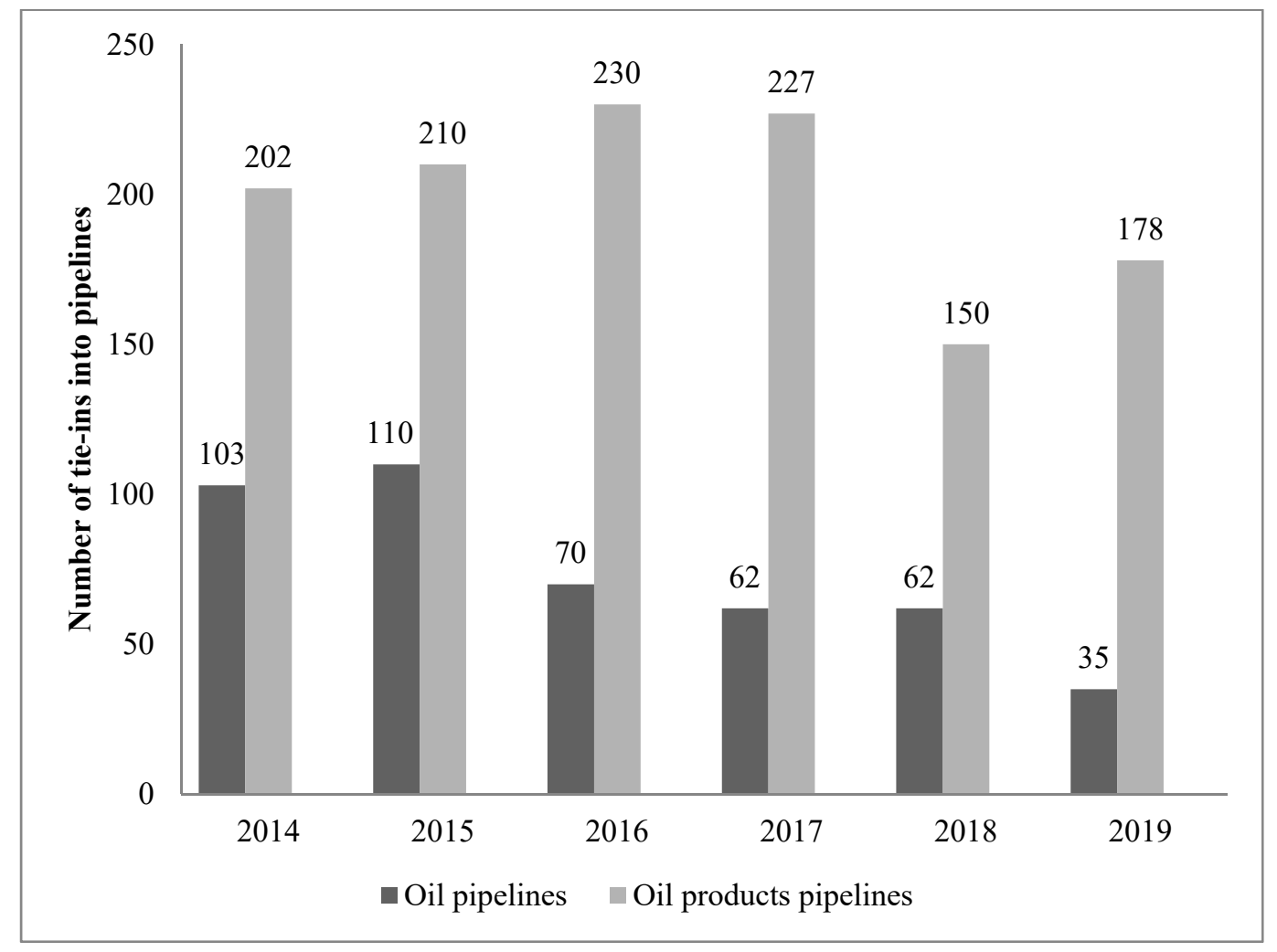

Figure 3. Number of unauthorized tie-ins in the main oil and oil products pipelines

From the data given in Figure 3, we can see that the number of tie-ins into oil pipelines is approximately twice as many as into oil ones. This is because of stolen oil products which cannot be processed, they are already ready for sale. In this regard, the problem of ensuring the integrity and reliability of pipelines is extremely urgent.

\section{Content Setting of the Management Task}

To prevent accidents in pipelines and to ensure their industrial and environmental safety in Russia, a comprehensive system of measures has been formed and continues to improve, including various groundbased technical control systems (ultrasonic, acoustic emission, laser gas analysis method, etc.), as well as ground and aerospace patrolling [4]. They allow monitoring pipelines in order to assess their technical condition to identify possible product leaks, unauthorized taps, environmental conditions, foreign equipment, and people in the pipeline laying area. Ground patrolling today is a fairly common form of control, but it has a lot of disadvantages. The main problem is that the length of main pipelines is many thousands of kilometers, they are often in areas with difficult weather and climatic conditions in the areas where the routes run, in difficult places with the complete absence or poor condition of along the thoroughfares, which makes it difficult to use allterrain vehicles and other ground equipment. In this situation, regular aerospace monitoring is used with satellites equipped with various equipment and helicopters, which complement ground-based types of control [5].

Unfortunately, these controls have a number of significant disadvantages. The maintenance of allterrain vehicles, their maintenance and repair, and the rental of helicopters for regular flights around pipelines require large material and financial costs, which is difficult even for large companies; moreover, all-terrain vehicles cannot travel long distances and have a traffic limit. The sensors are reliable, but require periodic verification, repair, replacement, and placing them along the entire length of the route fraught with great difficulties.

\section{Perspective Area for New Helicopter Technology}

A modern high-tech and effective tool that can be used to monitor main pipelines is UAV of a helicopter type with a long flight range. They combine the positive qualities of monitoring using manned aircraft: high speed, quality of object surveys, and mobility. But the cost of UAV flight hour is several times lower than the cost of manned aircraft of the same purpose.

Using UAV, we can search for leaks and the volume of spilled oil during hydrocarbon transportation, detect unauthorized taps in oil pipelines, monitor dangerous natural and technological processes that threaten damage to the linear part of the pipeline, and monitor the protection zone of the pipeline [6]. 
UAV is able to independently follow the given route, conduct photo and video shooting in real time, observe the linear part at night using thermal imaging and with the ability to detect unauthorized persons in the protected area.

Multifunction UAV are complex and high-tech products. They can be classified according to a lot of criteria: according to the purpose, type of take-off and landing, take-off weight, weight of payload, type of engines, type and composition of airborne equipment, flight performance, etc. [7], [8].

It seems appropriate in the framework of this study to identify the segment of a helicopter-type UAV that is intended for commercial use with the aim of monitoring long-distance oil and gas pipelines.

The flight technical and operational characteristics of UAV are determined by the tasks that it will have to solve and their complexity. Formation of reasonable requirements for UAV characteristics and their priority depends on customers. In turn, this will determine in the future the content of the research and development of the helicopter-building enterprise. One of the main flight and technical characteristics of UAV designed to patrol main pipelines interesting to a customer is the flight range. Other characteristics, such as payload mass and composition, flight duration and altitude, engine type, navigation type, software specialization, cost, etc., are also included in the list of requirements formed by the customer and must be agreed upon.

According to the Central Intelligence Agency of USA [9], published in the World FactBook in 2013, 112 countries had pipelines with various network lengths, 107 countries had oil pipelines, and 73 countries had oil pipelines. In Figure 2. there is the distribution of countries along the length of their network of main gas pipelines.

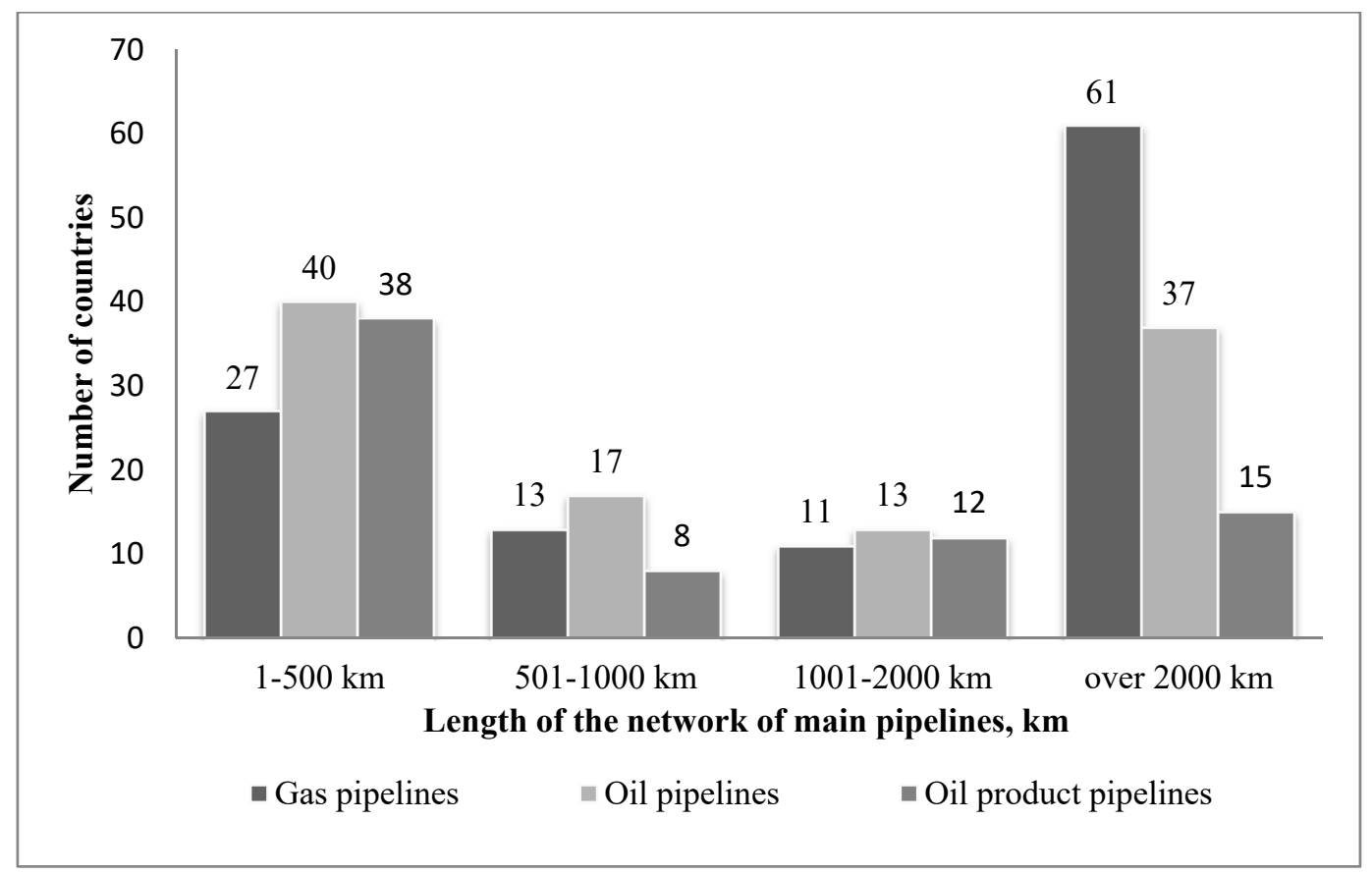

Figure 4. Distribution of countries along the length of the main pipeline network

Such a distribution of networks in length may be one of the parameters of the segmented market structure created by UAV. Further levels of segmentation can be determined by territorial, climatic, geographic, and other parameters related to the characteristics of each country [10], [11]. These features, in turn, will affect the characteristics of pipeline monitoring modes, its volumes, and flight and technical parameters of created UAV.

When choosing UAV parameters, in the general case, we can talk about the existence of several goals, and UAV developers and customers are interested in achieving them. It is not possible to evaluate all of these goals using one indicator (criterion): for example, flight range or its duration, due to the complexity and multivariance of solving the problem, uncertainty of the market situation affecting the interests of all project participants or persons involved in the transaction, which may be different. In a competitive environment, project developers must secure superiority over their competitors and, on this basis, form a specific business strategy that consists in creating a new competitive UAV for a specific market segment. To solve this kind of multicriteria problems, there are various methods: for example, reducing a multicriteria problem to a single-criterion allocation of the main indicator and its maximization (minimization). At the same time, some restrictions are imposed on the remaining indicators with the requirement that they need to be 
not less (more) than the set ones. We can use the method of successive concessions, etc. In any case, a field of alternatives that are selected according to a specific criterion or group of criteria is formed. For example, we can use the triad of criteria "timeefficiency-value". Depending on the specific purpose of the project and the competitive situation in the UAV market, any criterion from this triad can be selected. Sometimes the determining factor there is time [12].

To justify the direction of scientific and technological innovations in the formation of product requirements, when assessing and choosing sales markets, their capacity, methods of product sales, and its maintenance, it is necessary to use various sets of marketing technologies and tools. Reliable and representative information collected and processed as a result of marketing research can be used by the helicopter company's management to analyze the environment from an ecological, technological, and economic point of view, market attractiveness and, on this basis, prepare and make strategic decisions in planning their production and commercial activities. At this stage, the development is adapted to market conditions, the choice of the most commercially optimal segment by volume of demand and the requirements of direct customers-users of UAV. The strategic solution may be the maximum possible adaptation of the development and production of new unmanned helicopters to the requirements of various market segments and the production of UAV that are heterogeneous in terms of characteristics and, thus, stimulate demand [13].

Since the need for UAV is based on the need to monitor long-distance oil and gas pipelines to ensure the reliability and safety of its operation, the main customers of this kind of services are enterprises of the fuel and energy complex. They must also determine the requirements for the UAV and the volume of its supplies.

In the USA, for timely detection of problems on the oil pipeline and their prompt elimination, representatives of the Accenture energy group proposed the use of drones equipped with heatsensitive cameras to identify possible problems. Experts from the North American energy group note that a new area of oil pipeline monitoring using drones is being created in the American oil pipeline industry. The accuracy of measurements provided by unmanned helicopters is three times higher than when using aircraft, due to the ability to fly slower or to hang where it is needed, i.e. on rough terrain.

Many UAV models of various types have already been developed: aircraft and helicopter, with different types of engines, different flight performance, various purposes and uses (in Russia, USA, and China). They are successfully used to perform various kinds of geoinformation and telecommunication services, local survey of territories, delivery of small cargoes, mail, agriculture within a few kilometers, but for monitoring long-distance pipelines the use of existing helicopter-type UAVs is impossible due to their small radius of operation. Studies show that there is a real need for the creation of a helicopter-type UAV with flight performance characteristics capable of providing high-quality monitoring of long-range objects and highly efficient from an economic point of view. This is a real opportunity for a developing helicopter-building enterprise to diversify its activities and discover a new segment of a potentially commercially promising market.

In the short term, we should expect the appearance of various modifications of the helicopter-type UAV, created not only on the basis of manned prototypes, but originally developed as drones of a smaller dimension and, accordingly, with a lower flight hour cost. Their use will give a great economic effect. Moreover, the possibility of their double use in the interests of defense should not be ruled out.

\section{Conclusions}

Pipeline systems are available in many countries. Pipelines belong to the category of energy-stressed facilities, the failures of which are associated, as a rule, with significant material, financial and environmental damage with possible irreparable consequences for the environment. Constant monitoring of pipelines is required, which will allow us to assess the technical condition of the pipes, including a change in the spatial position of the pipeline due to environmental influences, mechanical damage, insulation failures, fistulas, cracks, leaks, accident situations from the point of view of the ecological state of the environment along the pipeline route, to reveal unauthorized product selection, to detect strangers in the protected area.

In addition to existing control methods, UAV of a helicopter type with a long flight range can become a modern high-tech solution to the problems of monitoring trunk pipelines. The measurement accuracy provided by unmanned helicopters is three times higher than when using aircraft, due to the ability to fly slower or to hang where it is needed, i.e. on rough terrain. The creation of such a UAV meets the basic needs of the society, has a high innovative and export potential. For a helicopter manufacturing enterprise, this may become a new and promising area of diversification, since the need for an economical helicopter-type UAV capable of monitoring long-distance objects: pipelines, energy networks, borders, etc., is very large and potentially the market will be highly efficient. 


\section{References}

[1].Ivanov, A. S., \& Matveyev, I. Ye. (2019). Sovremennaya mirovaya energetika: bor'ba za yedinstvo (tselostnost') eksportnoy politiki-vopreki napadkam iz-za okeana. Bureniye i neft', (10), 3-9.

[2].Khaustov, A. P., \& Redina, M. M. (2009). Chrezvychaynyye situatsii i ekologicheskaya bezopasnost' v neftegazovom komplekse. Khaustov, M. Redina-M.: Izd-vo GEOS, 456, 5.

[3].Kushnareva, O. V., \& Golubayev, D. V. (2018). Analiz prichin avariy na ob"yektakh magistral'nogo transporta nefti i gaza: problemy i resheniya. Master's Journal, (1), 37-43.

[4].Sevast'yanov, D. N., \& Lazutin, V. A. (2017). Ispol'zovaniye aerokosmicheskoy informatsii dlya resheniya zadach v oblasti ekologicheskogo kontrolya PAO «Gazprom». Gazovaya promyshlennost', (1), 88.

[5].Kolesov, K. I., Gankevich, K. A., Plekhanova, A. F., Ivanov, A. A., \& Karakush'yan, N. A. (2015). Ob aktual'nosti svoyevremennoy diagnostiki tekhnicheskogo sostoyaniya protyazhennykh zamknutykh ob"yektov. Trudy NGTU im. RE Alekseyeva, (3 (110)), 295-298.

[6].Minkin, D. Yu., Terekhin, S. N., Korolkov, A. P., \& Osmanov, Sh. A. (2017). Space thermal imaging monitoring of oil and gas pipeline transport. Fire and explosion safety, 26 (12), 45-51.
[7].M. N. Krasil'shchikov, D. A. Kozorez, K. I. Sypalo, et al.,(2009). Modern Information Technologies in Problems of Navigation and Guidance of Unmanned Maneuverable Flying Vehicles (Fizmatlit, Moscow, 2009) [in Russian].

[8].Green, D. R., \& Gomez, C. (1998). Small-scale airborne platforms for oil and gas pipeline monitoring and mapping. In Proceedings of the Marine and Coastal Environments Conference-San Diego, US (October 1998) (pp. 1-54).

[9].Zaripov, R. N., Murakaev, I. M., Novikov, S. V., \& Ryapukhin, A. V. (2020). Corporate Structure for Innovative Enterprises. Russian Engineering Research, 40, 137-139.

[10]. Deresky, H. (2000). International management: Managing across borders and cultures. Pearson Education India.

[11]. Aurifeille, J. M., Medlin, C., \& Tisdell, C. A. (2009). Trust, globalisation and market expansion. Nova Science Publishers.

[12]. Dmitriev, O. N., \& Novikov, S. V. (2019). Verification of Feasibility Studies at High-Technology Enterprises. Russian Engineering Research,39(9), 780-781.

[13]. Mohr, J. (2011). Marketing of high-technology products and innovations. Pearson Education India. 